\title{
Introduction
}

\author{
Kevin Curran
}

Shakespeare and Judgment. It's a simple enough proposition. "Shakespeare" and "judgment": two keywords, both fairly recognizable, each offering a context for the other. And yet the title of this book immediately raises some questions. First of all, what exactly is "judgment"? Is it an act or a process? A concept or an experience? To which cultural or theoretical field does it belong, and to what set of social practices? Also - and perhaps most importantly - what does it have to do with Shakespeare? Given how many items have appeared on the other side of the "Shakespeare and" formulation from religion, law, appropriation, the book trade, and national culture to masculinity, republicanism, Ovid, music, and language what justifies adding yet another? What, that is, does judgment offer Shakespeare studies as a category of critical inquiry? This introduction will begin to provide some answers to these questions, setting the scene for the more specific projects that follow. Grounding the volume are two core contentions: (1) that attending to Shakespeare's treatment of judgment leads to fresh insights about the imaginative relationship between theater, law, religion, and aesthetics in early modern England; and (2) that judgment offers new ways of putting the historical and philosophical contexts of Shakespeare's plays into conversation.

This is a new undertaking, the first attempt to articulate the central place of Shakespearean drama in the cultural and intellectual history of judgment. That said, the volume builds on a number of earlier studies. Richard Strier, for instance, discusses what he views as Shakespeare's skepticism about moral judgment in chapter three of The Unrepentant Renaissance: From Petrarch to Shakespeare to Milton, and returns to the idea in an essay called "Shakespeare and Legal Systems: The Better the Worse (but Not Vice Versa)." Julia Reinhard Lupton explores the idea of judgment at a number of points in Thinking with Shakespeare: Essays on Politics and Life, especially in a chapter devoted to The 
Winter's Tale which draws compelling parallels between Shakespeare's and Hannah Arendt's conceptions of judgment. Lupton extends this line of thought in a more recent essay dealing with the relationship between judgment and forgiveness in The Winter's Tale. ${ }^{2}$ Judgment is also discussed at various points in Lorna Hutson's seminal study of theater and law in early modern England, The Invention of Suspicion: Law and Mimesis in Shakespeare and Renaissance Drama. ${ }^{3}$ Hutson is primarily interested in the perception and practice of judgment within English common law, but she also examines the way ideas about legal judgment are connected to discourses of religion and civility in early modern England. The place of judgment within rhetorical theory has been addressed by Kathy Eden in Poetic and Legal Fiction in the Aristotelian Tradition, Joel Altman in The Improbability of Othello: Rhetorical Anthropology and Shakespearean Selfhood, and Quentin Skinner in Forensic Shakespeare. ${ }^{4}$ Paul Yachnin's chapter on "The Theater of Judgment" in his forthcoming book, Making Publics in Shakespeare's Playbouse, will constitute yet another significant contribution to this growing body of scholarship. ${ }^{5}$ Related work that deals with judgment beyond the historical parameters of early modernity includes, most importantly, Vivasvan Soni's special issue of The Eighteenth Century on "The Crisis of Judgment" and Thomas Pfau's wide-ranging inquiry into the roots of modernity, Minding the Modern: Human Agency, Intellectual Traditions, and Responsible Knowledge, which takes up judgment - along with will, personhood, and action - as one of the foundational concepts in Western intellectual history. ${ }^{6}$

As the notes to the chapters that follow indicate, Shakespeare and Judgment is in close conversation with these studies. Taken as a whole, though, the volume also offers something quite distinct: the first sustained consideration of the way judgment, in its various cultural and conceptual formations, shapes and is shaped by Shakespeare's language and dramaturgy. Such a project stands to reinvigorate our understanding of the imaginative and cultural geography of Shakespeare's plays, since judgment was, and remains, a point of intersection for a wide variety of social practices and intellectual traditions. Conversely, the plays themselves help us map out judgment's assemblage-like structure across the sprawled thought-worlds of law, religion, aesthetics, rhetoric, and philosophy. Shakespeare, of course, was not the only early modern dramatist to engage with judgment. Ben Jonson, for example, deals with it quite regularly. But Shakespeare's plays offer a richer, more wide-ranging account of what judgment is and what judgment can make possible (politically, ethically, and socially) than any of his contemporaries. 


\section{What is Judgment?}

Judgment is something out there - in the law courts, in the universities, on the tip of God's tongue, and in the codes of socialization. But it's also something in here. Judgment is a psychological faculty possessed by each person, even if its effectiveness may vary depending on circumstance and other factors. Early modern scholars such as Pierre de la Primaudaye, Thomas Wright, Philippe de Mornay, and others describe the capacity to judge as part of a complex ecology of cognitive and sensory aptitudes. Memory, for example, as Garrett Sullivan has shown, was thought of as crucial to judgment, providing a storehouse of experience-based data on which future decisions could be based. ${ }^{7}$ Emotion, on the other hand, conceived of in physiological terms and referred to as "passions," impeded judgment. In Passions of the Minde (1601), Thomas Wright explains,

Those actions then which are common with us, and the beasts, we cal Passions, and Affections, or perturbances of the mind ... They are called Passions (although indeed they be acts the sensitive power, or faculties of our soul . . .) because when these affections are stirring in our minds, they alter the humours of our bodies, causing some passion or alteration in them. They are called perturbations, for that . . they trouble wonderfully the soule, corrupting the judgment, \& seducing the will ...8

Similarly, Philippe de Mornay in The True Knowledge of a Man's Owne Selfe (1602) instructs that "The knowledge of a mans owne selfe, availeth, not onely for preservations of the bodies health, but likewise to moderate the vehemcie of inordinate affections, which hinder and impeach the health of judgment."

According to these writers, judgment is rational and practical, and in this sense quite opposed to the operations of the body. But this was not the only version of judgment made available by early modern faculty psychology. As David Summers has demonstrated, there is also "a long tradition of speculation concerning prerational sensate judgment upon which Renaissance writers drew." ${ }^{10}$ Aristotle, for example, argued that the capacity to judge was common to both thought and perception. "Each sense," he writes, "judges the specific differences of its own sensible object ... Sight produces upon white and black, taste upon sweet and bitter, and so with the rest." ${ }^{11}$ Later, we find the English scholar Abraham Fraunce advancing a similar line about the relationship between judgment and sensation in The Lawyers Logike (1588): 
For as Aristotle teacheth in the second of his demonstrations, every sensible creature hath a naturall power and facultie of judging, which is called sence; $\&$ this sence ( 2 . Topic) is of him sayde to bee a certayne kinde of judgement: and without doubt, the sence is a most upright judge of suche thinges as are properly under his jurisdiction, as the sight of colours, the hearing of soundes, the smelling of smelles (4. Metap). ${ }^{12}$

For Thomas Wright and Phillipe de Mornay, judgment is something that distinguishes humans from animals because it is a property of reason rather than sensation. For Fraunce, following Aristotle, however, judgment is common to "every sensible creature" because sensation constitutes a "certayne kinde of judgment."

It is the latter tradition that Shakespeare has in mind when Hamlet confronts his mother with portraits of her old husband, Hamlet Sr., and her new husband, Claudius:

This was your husband. Look you now what follows:

Here is your husband, like a mildewed ear,

Blasting his wholesome brother. Have you eyes?

Could you on this fair mountain leave to feed,

And batten on this moor? ha, have you eyes?

You cannot call it love, for at your age

The heyday in the blood is tame, it's humble,

And waits upon the judgment, and what judgment

Would step from this to this?

...

Eyes without feeling, feeling without sight,

Ears without hands or eyes, smelling sans all,

Or but a sickly part of one true sense

Could not so mope. $(3.4 .63-71,78-81)^{13}$

In the course of Hamlet's withering rebuke, judgment emerges as a species of spectatorship ("have you eyes?"). Good judgment, it seems, involves a clear alignment of perception and emotion while bad judgment (Gertrude's judgment) results from a misalignment of perception and emotion: "Eyes without feeling, feeling without sight." ${ }^{14}$

Faculty psychology underpinned much of the discourse on selfhood in early modern England, but the context in which most of Shakespeare's contemporaries would have encountered judgment was, in fact, the study of rhetoric. Roman rhetorical theory was central to the humanist curriculum in Tudor grammar schools. The Rhetorica ad Herennium, Cicero's De inventione, and Quintilian's 
Institutio oratoria were used as textbooks, offering students training in the kind of analytical and pragmatic method of argumentation central to what Aristotle called the genus iudiciale, or legal speech. ${ }^{15}$ This involved the carefully synchronized deployment of two skills: invention and judgment. Invention is the process of choosing the ideas and subjects most likely to persuade your audience while judgment is the process of ordering and deploying those ideas in a way designed to achieve maximum effect. In this context, judgment is best understood as "a faculty of form and structure, arranging the matter of invention by deciding which type of argument to use and how to compose a total sequence." 16 This formal dimension of judgment is noteworthy as it lies behind much of the vernacular literary criticism that emerged in the sixteenth and seventeenth centuries. Programmatic descriptions of good writing and right reading by figures such as Philip Sidney, George Puttenham, Samuel Daniel, and Henry Peacham cite judgment as both the faculty responsible for proper discernment and the attribute that stands to benefit from superior writing and oratory. The easiest way to identify first-rate poetry, so the argument runs, is to assess its level of decorum, the quality of adhering to formal rules of concurrence among genre, plot, character, and language. Decorum was the gold standard of aesthetic quality for early modern literary critics and it was understood primarily as an expression of sound judgment.

If the genus indiciale relied on a practical and evaluative version of judgment native to both humanist pedagogy and literary criticism, the term itself also reminds us that judgment found its primary institutional home in the law courts. In the case of legal pleas it took a form consistent with the requirements of humanist oratory. A plea, that is, involved both choosing and effectively arranging arguments. At the same time, judges, juries, and Justices of the Peace practiced judgment not just in the sense of handing down decisions, but also in the sense of using specific criteria to measure the quality and persuasiveness of legal arguments. In this respect, judges engage in a practice very similar to literary critics, a correspondence that Kathy Eden traces back to Aristotle:

The rapport between poetry and law, so fundamental to the Aristotelian literary tradition, is not only preserved but enriched. For, in an attempt to chart, for the first time, the invisible workings of psychological judgment, Aristotle turns ... to the familiar procedures of legal judgment. And this capacity for judging, in turn, is intimately linked in the human soul to the act of imagining, so crucial to both rhetoric and poetry. ${ }^{17}$ 
For the judge as for the poet or dramatist, judgment is a method. It is a procedure designed for measurement and assessment, for breaking things down into their component parts so as to evaluate them more effectively and understand them more accurately.

The Renaissance represents a particularly important passage in the professional and institutional history of legal judgment. The period saw a gradual shift in emphasis from legal doctrine to judge-made law, or jurisprudence, which meant that the role of judgment - of judicial decision-making - in creating the law expanded significantly. ${ }^{18}$ Whereas in the fifteenth century, Thomas Littleton's landmark Tenures (1481) relied almost exclusively on doctrine, or common learning, Sir William Staunford, holding the same judicial office as Littleton less than a century later, wrote, in J. H. Baker's words, "books so crammed with references and quotations that he seemed incapable of venturing an opinion unless it could be derived from someone else." 19 Staunford, in other words, in books like Les plees del coron (1557) and An exposicion of the kinges prerogative (1561), drew heavily on past judicial decisions to lend his own claims authority. Edmund Plowden's later sixteenth-century law reports exhibit the same tendency, but with more methodological rigor and decisiveness. Plowden was very selective when it came to choosing which cases to report. Unlike more typical yearbooks of the period, he would leave out any courtroom debate that was inconclusive, publishing only those cases in which a specific point of law had been settled by a final judgment of record. ${ }^{20}$ These shifts are indicative of a mounting desire among legal professionals and their clientele for law to rest upon clearly recorded facts. It resulted, gradually, in a more authoritative judiciary and judgment came to loom larger in the conceptual landscape of English common law. ${ }^{21}$

Despite the steadily growing importance of judgment - or perhaps because of it - there was also anxiety about the methods and effects of meting it out. Some of these anxieties were religious. Writings on the sacrament of penance, for example, frequently presented secular judgment as demonic, both severely formal and dangerously fallible in comparison with the equitable and restorative principles of the Church. ${ }^{22}$ One such text is Jacob's Well (c.1450), a sequence of penitential sermons composed for oral delivery between Ash Wednesday and the Vigil of Pentecost, now widely recognized as an early source for the morality play Mankind (c.1465). ${ }^{23}$ Each sermon fits into a larger allegorical scheme in which the soul struggles out of a pit of corrupt waters into the pure well of Jacob, assisted by various tools that represent contrition, confession, and satisfaction. The aim 
of these sermons was to urge parishioners to make confession and embrace the Church's penitential system for managing and purging sin. The diabolical alternative is the secular common law courts in which "thou schuldst be convict in thi cause, for thou art gylty in wrong ... and the sentens of dampnacyoun shulde be gouyn agens the." Better to go "to the juge of god, that is, to the preest." ${ }^{24}$ Whereas God's justice offers a shot at redemption, the inflexible justice of the common law courts leads directly to death and damnation. Hutson explains that in Jacob's Well, "jury trial emerges as no kind of trial at all, and salvation is imagined as a repeated escape from the rigors of Common Law Hell, first by the priestly judge's absolution, and then by Purgatorial pains, figured as our escape, by pleading clergy, to the canonical purgation of the spiritual courts."2.

The attitude toward secular judgment in Jacob's Well is indicative of a deeply entrenched habit of thought, a core distrust of secular law that persisted even despite the momentous shift in jurisdictional authority from spiritual to temporal institutions over the course of the sixteenth century. As late as 1578, Thomas Garter's dramatic interlude, The Commody of the most virtuous and Godlye Susanna, portrays a miscarriage of justice in a secular court set right at the last moment by divine intervention. Here, the concern is less with the diabolically stringent, either/or conditions of common law courts than it is with the basic competence of human judges, fallen and imperfect as they are, to identify truth and arbitrate accordingly. The Judge in Garter's interlude, persuaded by the false testimony of the elders, sentences Susanna to death. However, as "she is led to execution... . God rayseth the spiritte of Danyell," who insists that "they return all backe to judgment." ${ }^{26}$ In due course, Susanna is proclaimed innocent and the other participants in the trial roundly condemned. Garter's interlude is comforting to the extent that it portrays a caring God who intercedes on behalf of the downtrodden, but it certainly would not have left readers with much confidence in temporal judgment. Daniel refers to the members of the legal community in the interlude as "foolish folke ... that know not ill from good" 27 - hardly an endorsement of the efficacies of English common law.

Anxieties about the role of judges and the effects of their decisions can be found issuing from within the legal community, too. Edward Coke, for example, though confident enough that a judge would not completely misinterpret evidence and testimony, nevertheless urged those charged with the task of adjudication not to overstep their bounds. The role of the judge, Coke insisted, is to declare law, not to make it, "for that which hath been refined and perfected by the wisest 
men in former succession of ages, and proved and approved by continual experience to be good and profitable for the commonwealth, cannot without great hazard or danger be altered or changed." ${ }^{28} \mathrm{He}$ returned to the issue in his First Institutes, noting that "commonly a new invention doth offend against many rules and reasons of the common law, and the ancient judges and sages of the law have ever ... suppressed innovation and novelties in the beginning." ${ }^{29}$ Coke was not the only one to weigh in on the "hazard" of judicial innovation. John Davies makes a similar point in the preface to Le Primer Report des Cases en Ireland (1615) and Francis Bacon opens his essay "Of Judicature" with an extended statement on the matter:

Judges ought to remember that their office is jus dicere, and not jus dare; to interpret law, and not to make law, or give law. Else it will be like the authority claimed by the church of Rome, which under pretext of exposition of Scripture doth not stick to add and alter; and to pronounce that which they do not find; and by show of antiquity to introduce novelty. Judges ought to be more learned than witty, more reverend than plausible, and more advised than confident. Above all things, integrity is their portion and proper virtue. ${ }^{30}$

Judgment, Bacon asserts, is a strain of applied scholarship, not a maverick performance. He urges a kind of learned modesty and deference to legal doctrine. As long as the laws themselves speak through the judge, rather than vice versa, there is minimal risk of corruption and error.

The anxieties of jurists and clergymen notwithstanding, legal judgment was, with few exceptions, a thoroughly collaborative affair. It was a process involving multiple parties. We get a sense of how this worked in the manuals produced for Justices of the Peace in the period. Essentially printed how-to guides, these manuals were aimed at the gentlemen charged with presiding over the Quarter Sessions county courts that met four times per year (Epiphany, Easter, Trinity, and Michaelmas) - though they were no doubt consulted by other legal amateurs, too. Justices of the Peace were appointed annually and the primary qualification for the job was local standing, not legal expertise. They would hear cases having to do with comparatively minor offenses, such as trespass, assault, licenses for alehouses, and theft. ${ }^{31}$ Cases involving the most serious felonies, such as murder, were typically heard at the Assizes, which met twice per year and were presided over by professional barristers from the central courts. Responding to a clear need among England's many legal amateurs 
for procedural guidance, Justice of the Peace manuals began being printed in the late sixteenth century and increased steadily in popularity over the course of the seventeenth century. Almost all Justice of the Peace manuals went through multiple print runs and successive editions, so we can assume that they were in demand. Small books ranging in size from sixteenmo to octavo, they were meant to be carried around and referred to while on the job or shortly beforehand. Accordingly, the tone and style of the Justice of the Peace manuals tend to be practical and concise. From the mid-seventeenth century, in particular, a premium seems to have been placed on usability. The anonymously authored The Complete Justice (1637), for example, simply lists alphabetically a series of key technical terms and procedures followed by brief descriptions. This is a manual designed for quick and easy reference. The same format is adopted in The justice of peace, his clarks cabinet (1654), written by the prolific William Shepherd who also produced law lexicons and manuals for parsons, constables, and other minor legal professionals.

All of these texts show legal judgment to be a process involving various individuals working in close partnership. Take William Lambarde's Eirenarcha: or the office of the justices of the peace (1581). As an early example of the genre, Eirenarcha is more discursive and descriptive than its later seventeenth-century counterparts. Lambarde overviews the duties of Justices to their community, the central courts, the king, and God, and tries to differentiate between those situations in which strict conformity to certain recorded statutes is appropriate and when more discretionary judgment is called for. ${ }^{32}$ Significantly, during the lengthy discussion of the protocols of trial and sentencing, Lambarde describes this "Session of the Peace" as "An assemblie," and he stresses the fact that not one, but "two (or moe) Justices" must be present "to heare and determine" a case. ${ }^{33}$ This plurality of adjudicators is essential, and "if any of them be absent," Lambarde explains, "their fellow justices cannot amerce them ... for ... the auctoritie of all the Justices of the Peace at the Sessions is equall." 34 Lambarde goes on to describe in some detail each of the other figures who must be present for a trial to go forward and judgment to be passed: the "Shirife," the "Baylifes," and the "Juries," which "ought to containe 12. in number at the leaste." 35 Eirenarcha presents judgment as a participatory "assemblie," one in which complex bureaucratic procedures knit together a diverse network of both amateur and professional legal agents. Michael Dalton, a member of Lincoln's Inn, stresses this point too, opening his manual, The Countrey Justice (1618), with a narrative sketch of where the Justice of the Peace stands within the larger 
legal hierarchy and what that position affords in terms of specific duties, obligations, and dependencies. ${ }^{36}$

At the heart of these Justice of the Peace manuals is a fascination with breaking the legal process, especially adjudication, down into its most essential components. This concern with itemization and procedural detail can be found in other kinds of writing, too. Richard Bernard's stunningly dense allegory, The Isle of Man, or, The legall proceedings in Man-shire against sinne (1627), is a good example. In this narrative, self-examination, self-management, and self-regulation are figured through the collaborative procedures of common law. Conscience is represented by the Judge, but this judge operates within a diverse cluster of Justices and other officials:

The Justices of Peace in the Countrie are there, and doe sit with the Judge and are in Commission with him. Of these some are of the Quorum, and of the better ranke, some are meaner Justices and take their place lower.

The Justices of Peace in the Soule of better ranke are Science, Prudence, Providence, Sapience: the inferiors are Weake Wit, common Aprehension, and some such like.

These Justices have their Clerkes, there ready with their examinations and recognizances. Justice Science, his Clerke is Discourse: Justice Prudence, his Clerke is Circumspection, Justice Providence, his Clerke is Diligence; Justice Sapience, his Clerke is Experience: Justice Weake-wit, his Clerke is Conceit: and Justice Common-Apprehension, his Clerke is onely Sense. ${ }^{37}$

Bernard turns common law into a precise language of cognitive process and spiritual struggle, signaling what Hutson describes as "a new moral confidence . . . in the procedural detail of the Common Law." ${ }^{38}$ The allegory demonstrates the power of common law adjudication as an emblem of collaborative decision-making and as a figure for the concatenation of forces involved in moral choice. ${ }^{39}$

One thing that all the types of judgment considered here have in common is a fundamentally social, or at least relational, structure. In faculty psychology, judgment forms an evaluative interface with the outer world of people and things. In the rhetorical tradition, judgment aims at address and response; it presupposes the presence of an other. Legal judgment is a distributed, participatory event. Even when judgment is invoked in the context of self-knowledge, as it is by Stephen Guazzo in his conduct book, The Civile Conversation (1581), it is presented as a capacity that links the individual to a larger scene of sociality: "The judgment which we have to know ourselves is not ours, but we borrow it of others ... the knowledge of 
ourselves, dependeth of the judgment and conversation of many." 40 To this extent, early modern judgment, in all its various intellectual and institutional iterations, participates in a long philosophical tradition that views judging as a means of connecting the individual to larger collectives. This line of thought begins with Aristotle and the Stoics and is taken up with particular rigor in the eighteenth century when writers like the Third Earl of Shaftesbury, Jean-Jacques Rousseau, and Immanuel Kant formulated new ideas about the role of judgment in social and political life.

Particularly influential was Kant's famous argument that judging requires an "enlarged mentality," a form of decision-making based on a combination of one's own intuitions and the range of other possible intuitions held by those with whom you share a particular space or community. He describes it as "a power to judge that ... takes account (a priori), in our thought, of everyone else's way of presenting [something], in order as it were to compare our own judgment with human reason in general." ${ }^{41}$ Hannah Arendt, Kant's most astute modern interpreter, makes a similar argument: "As logic, to be sound, depends on the presence of the self, so judgment, to be valid, depends on the presence of others"; "Judging," she continues, "is one, if not the most, important activity in which this sharing-the-world-withothers comes to pass." ${ }^{42}$ In a serries of essays and lectures produced between 1961 and 1975, Arendt explored this link between judgment and collective perception at a level of nuance that surpassed any other twentieth-century philosopher. In this body of work, Arendt is particularly adept at drawing out the political and ethical implications of Kant's theories. In her essay "The Crisis in Culture," for example, she explains,

That capacity to judge is a specifically political ability in exactly the sense denoted by Kant, namely, the ability to see things not only from one's own point of view but in the perspective of all those who happen to be present; even that judgment may be one of the fundamental abilities of man as a political being insofar as it enables him to orient himself in that public realm, in the common world. ${ }^{43}$

Pushing this assertion further, Arendt maintains that aesthetic judgment, or "taste," should be understood in the same terms:

Taste, insofar as it, like any other judgment, appeals to common sense, is the very opposite of private feelings. In aesthetic no less than political judgments, a decision is made, and although this decision is always 
determined by a certain subjectivity, by the simple fact that each person occupies a place of his own from which he looks upon and judges the world, it also derives from the fact that the world itself is an objective datum, something common to all its inhabitants.

"For judgments of taste," Arendt concludes, "the world is the primary thing, not man, neither man's life nor his self." ${ }^{44}$ Arendt didn't look to early modern England to develop these arguments, but she could have. The central idea she advances - that judgment, broadly conceived, is interactive and participatory - is central to the period's understanding of adjudication. Shakespeare bears this out better than anyone.

\section{Shakespeare and Judgment}

As even this brief overview indicates, judgment is a more protean phenomenon than may at first appear to be the case. At once a faculty, a practice, a method, and a skill, judgment transforms as it migrates across the realms of psychology, rhetoric, aesthetics, law, religion, and philosophy. One implication of this multidimensionality is that judgment is difficult to contain within a single analytical framework. Accordingly, the chapters in this volume speak from a range of methodological platforms and engage a variety of different aspects of early modern culture, the history of ideas, and critical theory. The result, I hope, is a book that advances an intellectually diverse but still coherent account of the way judgment brings various discourses about justice, religion, beauty, selfhood, time, and performance into contact in Shakespeare's plays.

The chapters in Shakespeare and Judgment have been grouped in such a way so as to let the complexities of these crossings emerge. Themed subsections denote fields of action and experience that comprise different forms of judgment (legal, aesthetic, moral, etc.), rather than building artificial walls between them. Part I, "Staging Judgment: Deliberation in the Plays," presents three chapters on the performance of judgment in the playworld itself. Virginia Lee Strain's chapter, "Preventive Justice in Measure for Measure," considers the Duke's treatment of Barnardine's case at the end of the play. Frequently grouped among Measure for Measure's several concluding anomalies, Strain shows that there is, in fact, a compelling ethical logic to the Duke's decision. This emerges into view when we read the scene in the context of "preventive justice," a frequently overlooked 
aspect of legal theory and practice, both in early modern studies and legal studies. Moving from legal history to intellectual history, Vivasvan Soni's "Believing in Ghosts, in Part: Judgment and Indecision in Hamlet" discusses the failure of modern philosophers to differentiate sufficiently between decision and judgment in Hamlet, arguing for the centrality of the former to the play's treatment of both time and subjectivity. Constance Jordan closes the section with a turn to material and professional contexts. Her chapter, "Shakespeare's Law and Plowden's Authority," considers how judgment in The Taming of the Shrew is shaped by developments in the practice of law reporting in the sixteenth century.

Part II, "Audience Judgment: Deliberation in the Theater," features four chapters that expand the frame of reference to include not just the fictional playworld, but also the cognitive, interpretive, and participatory dynamics of theatrical spectatorship. Katherine B. Attié opens the section with a chapter called "Gently to hear, kindly to judge': Minds at Work in Henry V." In it, she demonstrates that in the case of Henry $V$, audience judgment is linked not to law, but rather to a specifically early modern understanding of the intellectual and ethical labor of playgoing itself, one that runs counter to the famous antitheatrical equivalence between theatrical spectatorship and idleness. Carolyn Sale's chapter, "Practis[ing] judgment with the disposition of natures': Measure for Measure, the 'Discoursive' Common Law, and the 'Open Court' of the Theater," shifts the discussion from labor back to law. Focusing on Measure for Measure, she argues that the play in performance offers audiences the opportunity to experience their own authority in relation to the common law's "discoursive" practices of judgment. Paul Yachnin takes us deeper into this play in his chapter, "The Laws of Measure for Measure." Like Strain in the previous section, Yachnin is interested in the apparent strangeness of the Duke's judgments in Act 5. But whereas Strain explains it by reference to the history and theory of preventive justice in early modern England, Yachnin views it as an example of the law-making capacity of Shakespeare's theatrical art. By defamiliarizing legal judgment in institutional and historical terms, Measure for Measure creates its own legal system. That is to say, it opens a participatory space within the theater where playgoers can engage in the sort of collective evaluation and moral decision that gives meaning and value to the world. Kevin Curran concludes the section with a chapter called "Prospero's Plea: Judgment, Invention, and Political Form in The Tempest." Curran shows, first, that the connection Prospero establishes between judgment and invention in 
the epilogue grows out of early modern rhetorical theory. He then goes on to argue that in translating this tradition into the language of performance, the epilogue makes a uniquely theatrical contribution to a modern body of thought on the relationship between judgment, politics, and form.

The final section of the volume, "The Ethics of Judgment," opens out to a broader set of historical and conceptual questions. Featuring three very different kinds of inquiries, the section offers a wide-ranging meditation on how judgment indexes the larger religious, philosophical, and critical contexts for the way social and moral value is determined. John Parker's “Antinomian Shakespeare: English Drama and Confession across the Reformation Divide" explores how Shakespeare tends to figure forgiveness as an escape from legal and moral judgment. Shakespeare's skepticism about judgment, Parker argues, follows from Christianity's ongoing and sometimes quite radical critique of the law. Sanford Budick's rigorously philosophical chapter, "Bracketed Judgment, 'Un-humanizing', and Conversion in The Merchant of Venice," reflects on the way Shakespeare uses judgment in the trial scene to create an impossible moral dilemma, one that actually suspends the audience's own ability to judge. Though at first glance paradoxical, Budick shows through careful philosophical contextualization that this suspension of judgment is in fact one of the play's most powerful and systemic ways of creating human community. Concluding the section, and the volume, is Richard Strier's chapter, "The Judgment of the Critics that Makes us Tremble: 'Distributing Complicities' in Recent Criticism of King Lear." In a move that will leave many readers reflecting not just on Shakespeare's plays, but also on their own professional practice, Strier steps outside of staged fictions, outside of the theater, and outside of early modern culture to consider instead the kind of judgment exercised in the world of Shakespeare criticism. Focusing on Stanley Cavell's and Harry Berger Jr.'s influential work on King Lear, Strier argues for a mode of literary-critical judgment based on surface rather than depth and on common sense rather than convolution. Judgment, he reminds us, is not just an instinctive response, but a deliberate craft involving stylistic and hermeneutic choice. If we want literary criticism to have real intellectual and ethical purchase, we need to think carefully about how that craft is practiced.

My hope for this volume is that it will offer readers new ways to frame the historical and intellectual contexts of Shakespeare's plays, such that neglected areas of conceptual overlap begin to emerge. 
Rooted as it is in so many different aspects of cultural practice and philosophical speculation, judgment stands to make a uniquely generative contribution to Shakespeare studies by opening new spaces of encounter among early modernists working with law, religion, rhetoric, theater history, and critical theory.

\section{Notes}

1. Richard Strier, The Unrepentant Renaissance: From Petrarch to Shakespeare to Milton (Chicago: University of Chicago Press, 2011) and "Shakespeare and Legal Systems: The Better the Worse (but Not Vice Versa)," in Shakespeare and the Law: A Conversation Among Disciplines and Professions, ed. Bradin Cormack, Martha C. Nussbaum, and Richard Strier (Chicago: University of Chicago Press, 2013), 174-200.

2. Julia Reinhard Lupton, Thinking with Shakespeare: Essays on Politics and Life (Chicago: University of Chicago Press, 2011) and "Judging Forgiveness: Hannah Arendt, W. H. Auden, and The Winter's Tale," New Literary History 45 (2014): 641-63.

3. Lorna Hutson, The Invention of Suspicion: Law and Mimesis in Shakespeare and Renaissance Drama (Oxford: Oxford University Press, 2007).

4. Kathy Eden, Poetic and Legal Fiction in the Aristotelian Tradition (Princeton: Princeton University Press, 1986); Joel B. Altman, The Improbability of Othello: Rhetorical Anthropology and Shakespearean Selfhood (Chicago: University of Chicago Press, 2010); and Quentin Skinner, Forensic Shakespeare (Oxford: Oxford University Press, 2014).

5. Paul Yachnin, Making Publics in Shakespeare's Playhouse (Edinburgh: Edinburgh University Press, forthcoming 2017).

6. Vivasvan Soni, ed., The Eighteenth Century: Theory and Interpretation 51 (2010), Special Issue on "The Crisis of Judgment"; Thomas Pfau, Minding the Modern: Human Agency, Intellectual Traditions, and Responsible Knowledge (Notre Dame: Notre Dame University Press, 2013).

7. Garrett A. Sullivan, Jr., "'Be this sweet Helen's knell, and now forget her': Forgetting, Memory, and Identity in All's Well that Ends Well," Shakespeare Quarterly 50 (1999): 51-69. In this section I have relied heavily on Sullivan, whose work on memory and forgetting returns regularly to the notion of judgment in early modern faculty psychology. See also his book Memory and Forgetting in English Renaissance Drama: Shakespeare, Marlowe, Webster (Cambridge: Cambridge University Press, 2005). 
8. Thomas Wright, The Passions of the Minde in Generall (London, 1601), 12-14; quoted in Sullivan, "'Be this sweet Helen's knell'," 57.

9. Philippe de Mornay, The True Knowledge of a Man's Owne Selfe (London, 1602), 2.

10. David Summers, The Judgment of Sense: Renaissance Naturalism and the Rise of Aesthetics (Cambridge: Cambridge University Press, 1987), 22. Also relevant here is Heidi Cephus, "Corporeal Judgment in Shakespeare's Plays" (PhD diss., University of North Texas, 2016), which makes an important contribution to this line of inquiry.

11. Aristotle, De Anima (On the Soul) (London: Penguin, 1986), 426b-c.

12. Abraham Fraunce, The Lawyers Logike (London, 1588), 91.

13. G. Blakemore Evans, gen. ed., The Riverside Shakespeare, $2 \mathrm{~d}$ ed. (Boston: Houghton Mifflin, 1997). The version of this speech in Evans's edition includes the lines from the First Quarto (1603) that are not present in the First Folio (1623).

14. I develop this idea further in a forthcoming essay called "Judgment and Emotion in Hamlet."

15. See Peter Mack, Elizabethan Rhetoric: Theory and Practice (Cambridge: Cambridge University Press, 2002); and Skinner, Forensic Shakespeare, $11-47$.

16. Henry S. Turner, The English Renaissance Stage: Geometry, Poetics, and the Practical Spatial Arts, 1580-1630 (Oxford: Oxford University Press, 2006), 50.

17. Kathy Eden, Poetic and Legal Fiction in the Aristotelian Tradition (Princeton: Princeton University Press, 1986), 63.

18. John Langbein, Prosecuting Crime in the Renaissance: England, Germany, France (Cambridge, MA: Harvard University Press, 1974), 104-28; "The Criminal Trial Before the Lawyers," University of Chicago Law Review 45 (1978): 263-316; J. S. Cockburn, Calendar of Assize Records: Introduction (London: Her Majesty's Stationery Office, 1985), chs. 6, 8, and Conclusion; J. H. Baker, The Legal Profession and The Common Law: Historical Essays (London: The Hambledon Press, 1986), 474-6.

19. Baker, Legal Profession, 474.

20. See, for example, Edmund Plowden, Les commentaries, ou les reportes de Edmunde Plowden (London, 1571) and Cy ensuont certeyne cases reportes per Edmunde Plowden (London, 1579).

21. Baker, Legal Profession, 461-76; J. H. Baker, An Introduction to English Legal History (Oxford: Oxford University Press, 2002), 195-9; Cynthia Herrup, The Common Peace: Participation and the Criminal Law in Seventeenth-Century England (Cambridge: Cambridge University Press, 1987), 158-9.

22. Hutson, The Invention of Suspicion, 30-7. 
23. Sister Mary Coogan, An Interpretation of the Moral Play (Washington, DC: Catholic University of America Press, 1947); Leo Caruthers, "The Liturgical Setting of Jacob's Well," English Language Notes 24 (1987): $11-24$.

24. Arthur Brandeis, ed., Jacob's Well, an English treatise on the cleansing of man's conscience, Early English Text Society 115 (Oxford: Oxford University Press, 1900), 256-7.

25. Hutson, The Invention of Suspicion, 37-8.

26. Thomas Garter, The Commody of the most virtuous and Godlye Susanna (London, 1578), E1v, E2r.

27. Ibid., E1v.

28. Edward Coke, Le Quart Part des Reportes del Edward Coke (London, 1604), B2v.

29. Edward Coke, The First Part of the Institutes of the Laws of England (London, 1628), 379.

30. Francis Bacon The Major Works, ed. Brian Vickers (Oxford: Oxford University Press, 2002), 446.

31. The best primary sources for the Quarter Sessions are William Lambarde, Eirenarcha: or the office of the justices of the peace (London, 1581); and Michael Dalton, The Countrey Justice (London, 1618). For the Assizes, see J. S. Cockburn, ed., Calendar of Assize Records, 11 vols. (London: Her Majesty's Stationery Office, 1975-1985); Cockburn, A History of English Assizes, 1558-1714 (Cambridge: Cambridge University Press, 1972); Cockburn, "Early Modern Assize Records as Historical Evidence," Journal of the Society of Archivists 5 (1975): 215-31.

32. Lambarde, Eirenarcha, 57-8, 455.

33. Ibid., 286.

34. Ibid., 294-5.

35. Ibid., 304, 308.

36. Dalton, Countrey Justice, 4-6, 13-17, 23-7.

37. Richard Bernard, The Isle of Man, or, The legall proceedings in Manshire against sinne (London, 1627), 129-30.

38. Hutson, The Invention of Suspicion, 43.

39. See further, chapter 4 of my book, Shakespeare's Legal Ecologies: Law and Distributed Selfhood (Evanston: Northwestern University Press, forthcoming 2017).

40. Stephen Guazzo, The Civile Conversation (London, 1581), 4-5.

41. Immanuel Kant, Critique of Judgment, trans. Werner S. Pluhar (Indianapolis: Hackett Publishing Company, 1987), 160.

42. Hannah Arendt, "The Crisis in Culture: Its Social and Its Political Significance," in Between Past and Future: Eight Exercises in Political Thought (Harmondsworth: Penguin, 1993), 197-226.

43. Ibid., 221. 
44. Ibid., 222. For more of Arendt's work on judgment, see "Truth and Politics," in Between Past and Future, 227-64; "Personal Responsibility Under Dictatorship" and "Some Questions of Moral Philosophy," in Responsibility and Judgment, ed. Jerome Kohn (New York: Random House, 2003), 17-48, 49-146; The Life of the Mind (San Diego: Harcourt, 1978), 69, 93-5, 193. In addition to the two completed volumes of The Life of the Mind - "Thinking" and "Willing" - Arendt had intended to produce a third, on "Judging." She died before she was able to complete this section but much of the raw material for it can be found in the appendix to the Harcourt edition (255-72), "Judging: Excerpts from Lectures on Kant's Political Philosophy."

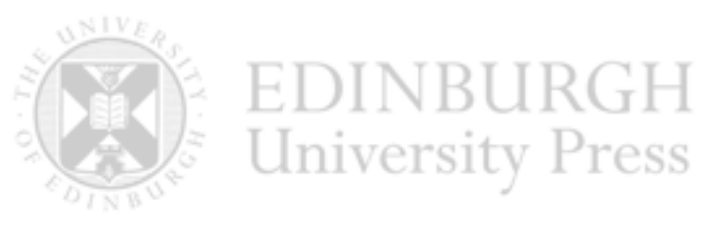

